\title{
LAYANAN TERHADAP GURU: PEMBELAJARAN SAINS ASPEK KIMIA PADA GURU-GURU IPA SMP
}

\author{
Ida Bagus Nyoman Sudria, dkk \\ ${ }^{1}$ FMIPA Universitas Pendidikan Ganesha
}

\begin{abstract}
Abstrak
Hampir semua guru mengalami kesulitan dalam pembelajaran kimia untuk siswa SMP yang mulai memberdayakan kajian mikroskopik untuk menjelaskan fenomena kimia konkrit dan representasi simbol kimia (rumus kimia). Kegiatan pelatihan pembelajaran sains aspek kimia SMP ini bertujuan 1) meningkatkan penguasaan konsep-konsep dasar kimia, (2) meningkatkan kemampuan merancang, mengimplementasikan, dan menyempurnakan sejumlah model-model pembelajaran yang saling menguatkan dalam pembelajaran sains kimia, dan (3) meningkatkan apresiasi guru-guru IPA SMP dalam pemeblajaran sains aspek kimia, serta mengidentifikasi kendala-kendala dalam pelaksanaan program pelatihan. Strategi pencapaian tujuan melibatkan sosialisasi dan pembuatan kesepakatan jadwal pelaksanaan program, pembekalan materi aspek kimia SMP, pelatihan analisis konsep, pelatihan/pendampingan pengembangan tiga jenis model pembelajaran (RPP dan kelengkapannya) melalui workshop, pendampingan implementasi model pembelajaran di kelas, dan melakukan refelksi dan penyempurnaan model pembelajaran yang dihasilan berdasarkan data implemnetasi di kelas. Metode pengumpulan data hasil kegiatan disesuaikan jenis data yang diperlukan pada setiap tahapan kegiatan. Karya utama dari kegiatan ini berupa (1) program pelatihan, (2) hasil identifikasin dan analisis konsep, dan (3) tiga jenis model pembelajaran sains aspek kimia yang merepresentasikan variasi karakteristik konsep sains. Analisis semua data dilakukan secara deskriptif. Kegiatan P2M ini secara keseluruhan cukup berhasil dilihat dari antusiasme, tingkat partisifasi, peningkatan pengetahuan yang secara tidak langsung dapat dilihat dari produk analisis konsep dan RPP dari hasil kegiatan pelatihan, dan tanggapan positif dari guru peserta pelatihan dan siswa yang mengikuti pembelajaran di kelas dengan model pembelajaran yang dihasil dalam program pelatihan guru.
\end{abstract}

Kata-kata kunci: analisis konsep, model pembelajaran, aspek kimia, makroskopik, mikroskopik, dan simbolik

\section{PENDAHULUAN}

Guru-guru IPA SMP di Kecamatan Tejakula yang tergabung dalam wadah MGMP Kecamatan menyadari dan memerlukan bantuan untuk mengatasi kesulitan mengajarkan sains aspek kimia sebagai bagian integral dari kompetensi-kompetensi bahan kajian sains dalam KTSP 2006. Guru-guru IPA SMP menganggap kompetensi kajian materi dan sifatnya (sains aspek Kimia) dengan alokasi waktu sekitar 1 SKS sebagai bidang baru di SMP. Kebutuhan pelatihan pengembangan program pembelajaran sains kimia SMP secara bermakna sesuai dengan perkembangan siswa 
SMP diperkuat oleh pernyatan Ketua MGMP Kecamatan Tejakula yang diketahui oleh Kepala Unit Pelaksana Pendidikan (UPP) Kecamatan Tejakula. Keluhan kesulitan pemebelajaran kimia oleh guru-guru IPA SMP juga terungkap dalam forumforum ilmiah terkait dengan pembelajaran kimia dalam dekade terakhir. Keadaan demikian sangat rasional. Guru-guru IPA SMP kurang memiliki latar belakang pendidikan Kimia yang memadai. Sebelum pelaksanaan Kegiatan ini, belum pernah secara berarti mendapatkan inservice pembelajaran kimia untuk siswa SMP.

Rendahnya kualitas pembelajar aspek kimia di SMP juga diungkap oleh guruguru Kimia jenjang SMA/SMK. Keluhan dari banyak guru-guru kimia SMA tersebut disampaikan kepada pengusul ketika bertugas membimbing mahasiswa PPL di SMA. Mereka mengeluhkan bahwa kebanyakan siswa kelas X SMA tidak memiliki secara memadai pengetahuan kimia yang semestinya sudah diajarkan pada jenjang SMP dan mempertanyakan efektifitas implementasi KBK 2004 dan KTSP 2006 untuk pembelajaran bahan kajian materi dan sifatnya di SMP.

Tim pelaksana sangat menyadari hal ini, apalagi ketua tim sangat intensif mengkaji kesulitan-kesulitan pembelajaran aspek kimia di SMP sejak tahun 2000 dalam rangka turut mewujudkan masyarakat melek sains (termasuk kimia) sebagai sasran paradigma pendidikan Science for All untuk hidup dalam zaman sains dan teknolgi yang terus berkembang dengan cepat. Sekarang sudah saatnya mengajarkan kajian materi dan sifat (aspek kimia) kepada siswa SMP, bukan karena program "wajib belajar sembilan tahun" semata. Materi dan sifatnya merupakan kebutuhan dasar hidup dan bahkan reaksi kimia merupakan proses hidup itu sendiri. Kualitas pemahaman materi dan sifatnya menentukan kualitas hidup baik perorangan maupun masyarakat. Kasus penyalahgunaan dan kekurangtepatan penggunaan bahan makanan, obat, dan pakaian marak terjadi terutama pada masyarakat yang tidak melek sains aspek kimia. Sementara profesionalisme pembelajaran sains aspek kimia secara bermakna yang melibatkan pengaitan kajian aspek makroskopik (sifat konkrit), aspek mikroskopik (partikel penentu sifat materi), dan simbolik (terutama rumus kimia sebagai identitas materi) pada siswa SMP (pemula dalam belajar kimia) menuntut perhatian khusus terutama dalam penumbuhan minat belajar kimia dan penanaman konsepsi awal secara benar tentang konsep-konsep dasar kimia untuk mencegah terjadinya miskonsepsi yang resisiten tentang konsep-konsep yang sangat mendasar seperti zat, unsur, senyawa, campuran, dan reaksi kimia. 
Pembelajaran materi dan sifatnya hendaknya diajarkan dengan benar dan bermakana pada siswa SMP. Jika masalah ini tidak diatasi akan berdampak pada keterbelakangan yang menyebar secara estapet pada generasi muda mengikuti deret ukur (eksponensial). Kualitas hidup masyarakat cendrung menurun, karena tidak bisa mewaspadai dan tidak bisa menggunakan secara benar dan efektif terutama bahan dan produk industri yang terus membanjiri pasar.

Dari tahun 2002-2006, ketua tim secara khusus mencari solusi terhadap permasalahan di atas. Melalui karya disertasi yang berjudul Pengembangan Materi Pemelajaran Kimia di SMP dalam Rangka Pendidikan "Science for All" (Sudria, 2006) berhasil diformulasikan materi-materi pembelajaran aspek kimia dengan mempertimbangkan keterkaitan kajian tiga aspek penting (aspek makroskopik, mikroskopik, dan simbolik) dalam belajar kimia secara bermakna sesuai dengan jenjang siswa SMP (pebelajar kimia pemula). Pengusul berhasil pula mengembangkan tiga model pembelajaran sains aspek kimia SMP. Secara keseluruhan, ketiga model cukup merepresentasikan strategi pembelajaran sains secara efektif. Ketiga model pembelajaran tersebut adalah (1) model pembelajaran zat dan campuran berbasis kegiatan laboratorium pada siswa kelas VII yang menekankankan pada upaya penumbuhan minat belajar kimia pada siswa SMP; (2) model pembelajaran unsur, senyawa, dan campuran berbantuan interaktif komputer untuk siswa kelas VIII yang menekankankan pada pembelajaran bentuk partikel materi sebagai dasar pemberian rumus kimia suatu zat dengan memulai dari penggunaan contoh-contoh zat dengan partikel (rumus kimia) sederhana dalam rangka belajar bermakna (mengurangi belajar hafalan); dan (3) model pembelajaran kimia dalam kehidupan sehari-hari berbasis proyek sains yang menekankan pendekatan sains-teknologi-masyarakat (STM).

P2M ini bertujuan untuk (1) meningkatkan penguasaan konsep-konsep dasar kimia dari guru-guru IPA SMP, (2) meningkatkan kemampuan guru IPA SMP untuk merancang/mengembangkan, mengimplementasikan, dan menyempurnakan sejumlah model pembelajaran yang saling menguatkan dalam rangka pembelajaran sains kimia yang komprehensip dan bermakna sesuai dengan perkembangan belajar siswa SMP, (3) meningkatkan apresiasi guru-guru IPA dalam mengajar sains aspek kimia di SMP, dan (4) mengidentifikasi kendala-kendala dalam pelaksanaan program. Keberhasilan kegiatan P2M ini diharapkan dapat diketoktularkan melalui media komunikasi ilmiah dan/atau perluasan pelatihan pada guru-guru IPA SMP lain. 


\section{MATERI DAN METODE}

Materi pelatihan memfokuskan pada penguasaan konsep melalui pembekalan materi dan analisis konsepsi, dan tiga jenis model pembelajaran konsep-konsep dasar yang dibutuhkan untuk kimia secara bermakna bagi pemula (SMP). Kajian materi dan sifatnya (aspek kimia) dalam buku-buku IPA SMP banyak yang membingungkan dan cendrung akan membunuh minat belajar kimia pada siswa seperti tuntutan penggambaran molekul-molekul glukosa dan sabun yang rumit dengan lambang ikatan kovalennya (siswa belum mengenal atau diajarkan ikatan kovalen, apa lagi lambang ikatan kovalen). Partikel-partikel materi atom, molekul, ion, dan rumusrumus kimia harus dihafal oleh siswa dan bahkan oleh gurunya.

Kesulitan mengajarkan kimia secara bermakana yang melibatkan keterkaitan kajian aspek makroskopis, mikroskopis, dan simbolik pada pebelajar pemula terletak pada pengenalan aspek mikroskopis (partikel materi) dan aspek simbolik (rumus kimia) yang berkesan abstrak. Sesungguhnya pelajaran kimia mikroskopis (struktur partikel materi) tidak abstrak dan rumus kimia pun terkait dengan objek nyata, tetapi karena ukuran partikel materi yang sangat kecil (tidak kasat mata) membawa kesan abstrak. Pengenalan aspek mikroskopis dan simbolik kimia pada siswa SMP harus menggunakan model-model kimia yang sesuai dengan perkembangan kognitif dan belajar siswa SMP. Sebagai contoh, bentuk molekul dengan model penggabungan bola-bola kecil (bola sebagai model atom) untuk menyajiakn model molekul cenderung lebih mudah dipahami dibanding dengan molel ball and stick yang melibatkan lambang ikatan kovalen yang belum dikenal siswa SMP dan pembelajaran lambang ikatan sendiri memerlukan alokasi maktu yang lama.

Contoh-contoh zat yang molekulnya akan disajikan hendaknya berupa zat yang memiliki molekul sederhana, bukan molekul besar/kompleks seperti glukosa ataupaun molekul sabun yang rumit. Jika zat-zat yang digunakan dalam kehidupan sehari-hari (sangat konteksual) harus diperkenalkan kepada siswa seperti glukosa (hasil fotosintesis) dan sabun dengan bentuk molekul yang rumit hendaknya cukup menggunakan gambar ilustrasi bentuk kasar/disederhanakan (tidak bentuk molekul sebenarnya). Jika ingin mengenalkan partikel-partikel materi yang rumit sebaiknya dikenalkan pada akhir kelas VIII atau pada kelas IX sebagai pengayaan.

Kesulitan-kesulitan yang dialami guru-guru IPA SMP di lapangan dalam mengajarkan kimia sangat beralasan, karena hampir semua guru-guru IPA SMP 
berlatar belakang Pendidkan Biologi atau Fisika dengan latar Pendidikan Kimia kurang memadai. Bahkan guru-guru IPA SMP yang berlatarbelakang formal Pendidikan Kimia dengan jumlah relatif sangat kecil juga mengalami masalah dalam pembelajaran Kimia untuk siswa SMP, karena mereka dipersiapkan menjadi guru Kimia SMA/SMK dan tidak dipersiapkan secara khusus untuk mengajar aspek kimia kepada siswa SMP.

Identifikasi dan analisis konsep-konsep dasar sains aspek kimia SMP dengan menggunakan format yang dikembngkan oleh Herron (1977) sangat bermanfaat bagi guru-guru IPA dalam menguasai konsep dan mengembangkan strategi pembelajarannya. Analisis konsep tersebut meliputi penentuan label konsep, definisi konsep (konsepsi), jenis konsep, ciri-ciri (attributes) kritis dan variabel, posisi konsep (supraordinate, ordinate, dan subordinate), contoh dan noncontoh. Tujuh jenis konsep dapat dikenali dari ciri kritis dan contohnya yakni 1) konsep konkrit (K), 2) konsep abstrak (Ab), 3) konsep dengan ciri kritis abstrak tetapi contohnya konkrit $(\mathrm{AbK}), 4)$ konsep berdasarkan prinsip (BP), 5) konsep yang melibatkan simbol (S), 6) konsep yang menyatakan proses (MP), dan 7) konsep yang menyatakan sifat (MS). Setiap informasi kimia (pengetahuan maupun prosedural) dapat dikategorikan menjadi salah satu dari ketujuh jenis konsep tersebut. Jenis konsep akan memberi pertimbangan dalam memilih strategi pembelajaran konsep tersebut.

Aspek-aspek yang harus diungkap dalam analisis konsep dengan menggunakan format Herron sangat berguna dalam perbaikan konsepsi pengembangan strategi pembelajaran konsep yang teridentifikasi. Melakukan analisis konsep sekaligus merupakan kegiatan refleksi bagi guru terhadap kualitas konsepsi ilmiah dari konsepkonsep yang akan diajarkan kepada siswa. Kegiatan demikian akan berdampak pada pembenaran suatu konsepsi terhadap miskonsepsi yang terjadi terhadap konsep tersebut. Identifikasi semua konsep penting dan konsepsi ilmiah dari masing-masing konsep tersebut sesuai dengan perkembangan siswa akan mengingatkan guru maupun siswa tentang isi belajar (konsep-konsep aspek kimia) yang benar dan harus dikuasai. Jenis konsep sesuai dengan ciri kritis konsep mengarahkan pendekatan dan metode pembelajaran yang efektif untuk pembelajaran konsep tersebut dan akan mencegah pembelokan fokus belajar. Ciri variabel dari konsep akan mengingatkan dan mengarahkan keluasan pengembangan konteks pembeljaran konsep tersebut. Sementara posisi konsep akan mengingatkan hubungan dengan konsep lain baik secara vertikal maupun horizontal yang akan meningkatkan kebermaknaan konsep. 
Ketepatan contoh dan noncontoh dari konsep mengontrol kebenaran dan ketepatan konsepsi dari konsep tersebut.

Kegiatan P2M ini mengembangkan tiga jenis model pembelajaran inovatif sains aspek kimia yang merepresentasikan variasi karakteristik konsep kimia. Ketiga model tersebut adalah model pembelajaran berbasis kegiatan laboratorium, model pembelajaran interaktif berbasis komputer, dan model pembelajaran berbais proyek sains. Karateristik ketiga jenis model disajikan dalam Tabel 1.

Tabel 1 Rasional, Outcomes, Sintak, dan Lingkungan Sosial dari Masing-Masing Model Pembelajaran.

\begin{tabular}{|c|c|c|}
\hline \multicolumn{3}{|c|}{ Program Pembelajaran } \\
\hline $\begin{array}{l}\text { Model Berbasis Kegiatan } \\
\text { Laboratorium (Aspek } \\
\text { Konkrit Zat dan Campuran }\end{array}$ & \begin{tabular}{|c|} 
Model Berbasis Kegiatan \\
Interaktif Komputer (Unsur, \\
Senyawa, \& Campuran)
\end{tabular} & \begin{tabular}{|} 
Model Berbasis Kegiatan \\
Proyek Sains (Kimia dalam \\
Masyarakat)
\end{tabular} \\
\hline $\begin{array}{l}\text { Rasional Teoritik: } \\
\text { - konstruktivis } \\
\text { - isi pelajaran: proses } \\
\text { prosedural konkrit dominan } \\
\text { (kemampuan dasar kimia) }\end{array}$ & $\begin{array}{l}\text { Rasional Teoritik: } \\
\text { • konstruktivis } \\
\text { - teknologi komikasi \& } \\
\text { informasi (TIK/ICT) } \\
\text { • isi pelajaran: proses kognitif } \\
\text { dengan obyek mikroskopik } \\
\text { dan simbol dominan (peng- } \\
\text { unaan model mikroskopik) }\end{array}$ & $\begin{array}{l}\text { Rasional Teoritik: } \\
\bullet \text { konstruktivis } \\
\bullet \text { kognitif } \\
\text { • behavioral } \\
\bullet \text { social } \\
\bullet \text { - isi pelajaran: proses } \\
\text { penemuan sains atau } \\
\text { pemecahan masalah }\end{array}$ \\
\hline $\begin{array}{l}\text { Outcomes pada siswa kelas } \\
\text { VII: } \\
\text { - penguasaan konsep dan } \\
\text { kemampuan kerja dasar kimia } \\
\text { - inkuiri }\end{array}$ & $\begin{array}{l}\text { Outcomes pada siswa kelas } \\
\text { VIII atau kelas VII: } \\
\text { - konsep dasar kimia } \\
\text { - diskoveri }\end{array}$ & $\begin{array}{l}\text { Outcomes pada siswa kelas } \\
\text { IX: } \\
\text { - penerapan konsep \& prosedur } \\
\text { dasar kimia } \\
\text { - inkuiri } \\
\text { - pemecahan masalah } \\
\end{array}$ \\
\hline $\begin{array}{l}\text { Sintak pembelajaran : } \\
\text { - pendekatan inkuiri } \\
\text { - metode eksperimen/ } \\
\text { percobaan } \\
\text { • kerja kelompok: mencermati } \\
\text { masalah/tujuan eksperimen, } \\
\text { melakukan eksperimen/ } \\
\text { percobaan, pengamatan, } \\
\text { pelaporan hasil, diskusi, dan } \\
\text { mengerjakan tugas pengayaan }\end{array}$ & \begin{tabular}{|l} 
Sintak pembelajaran: \\
- pendekatan diskoveri (inkuiri \\
terbimbing) \\
- metode interaktif komputer \\
- kerja kelompok mengenali, \\
menggolongkan, menyimpul- \\
kan, \& menjelaskan model- \\
model mikroskopik yang \\
diberikan; tugas pengayaan; \\
eksperimen, dan diskusi kelas
\end{tabular} & $\begin{array}{l}\text { Sintak pembelajaran: } \\
\text { • pendekatan STM - inkuiri } \\
\text { • metode proyek sains } \\
\text { • kerja kelompok } \\
\text { mengidentifikasi masalah di } \\
\text { masyarakat, identifika si sains } \\
\text { yang dapat diterapkan, dan } \\
\text { merancang solusi, melakukan } \\
\text { eksperimen, melaporkan hasil } \\
\text { (foster dan presentasi) }\end{array}$ \\
\hline $\begin{array}{l}\text { Lingkungan sosial kelas: } \\
\text { - kerja kelompok kecil } \\
\text { - siswa aktif (hand-on dan } \\
\text { mind-on) }\end{array}$ & $\begin{array}{l}\text { Lingkungan sosial kelas: } \\
\text { • siswa aktif } \\
\text { - mind-on } \\
\text { • Belajar melalui program } \\
\text { interaktif komputer }\end{array}$ & $\begin{array}{l}\text { Lingkungan sosial kelas: } \\
\bullet \text { Kerja kelompok kecil } \\
\text { • siswa aktif (mind-on \& hand- } \\
\text { on) } \\
\text { • masyarakat, laboratorium, } \\
\text { dan produk/teknologi kimia }\end{array}$ \\
\hline
\end{tabular}

Program pelatihan pembelajaran sains aspek kimia kepada siswa SMP melibatkan beberapa tahapan dengan metode yang disesuaikan dengan jenis tahapan kegiatan. Tahapan pelaksanaan kegiatan meliputi (1) sosialisasi dan pembuatan 
kesepakatan jadwal pelaksanaan program dengan metode tatap muka negosiasi (informasi, diskusi, dan akomodasi masukan), (2) pembekalan materi dengan metode informasi, diskusi, dan penugasan analisis konsepsi, (3) pelatihan pengembangan tiga jenis model pembelajaran (RPP dan kelengkapannya) dengan metode workshop yang didahului dengan pembekalan, (4) implementasi model pembelajaran di kelas dengan metode pendampingan penerapan program, dan (5) pendampingan terhadap guru untuk melakukan refelksi dan penyempurnaan model pembelajaran dengan metode presentasi dan diskusi hasil implementasi model pembelajaran di kelas.

Keberhasilan pelaksanaan kegiatan secara keseluruhan dapat dilihat dari antusiasme dan tingkat partisifasi peserta pelatihan, peningkatan pengetahuan yang secara tidak langsung dapat dilihat dari produk analisis konsep dan RPP dari hasil kegiatan pelatihan, dan tanggapan guru peserta terhadap keseluruhan kegiatan yang yang diikuti di kelas. Analisis semua data hasil kegiatan dilakukan secara deskriptif.

\section{HASIL DAN PEMBEHASAN}

Kegiatan P2M ini menghasilkan (1) program pelatihan, (2) hasil identifikasi dan analisis konsep-konsep dasar aspek kimia SMP, (3) tiga jenis model pembelajaran aspek kimia SMP, dan (4) tanggapan terhadap efektifitas model yang dikembangkan dari guru-guru peserta pelatihan dan siswa yang mengikuti model pembelajaran tersebut.

Program pelatihan secara keseluruhan memfasilitasi pencapaian tujuan pelatihan. Kelengkapan atau perangkat pelatihan meliputi (1) lima unit teks materi aspek kimia SMP yang disesuaikann dengan jenjang kelas (asam-basa kelas VII, zat dan campuran kelas VII, unsur dan senyawa kelas VIII, kimia di sekitar kelas VIII/IX, dan Kimia dalam Masyarakat untuk kela VIII/IX), (2) contoh analisis beberapa konsep dengan format Heroon (1977), (3) tiga contoh jenis model pembelajaran disertai lember kerja siswa (LKS) sesuai dengan model pembelajaran, dan contoh instrumen asesmen (tes, rubrik, dan angket) yang disesuaikan dengan sasarannya. Perangkat pelatihan tersebut telah memfasitasi kelancaran pelaksanaan tahapantahapan kegiatan pelatihan.

Secara keseluruhan, kegiatan P2M berhasil dengan baik. Tahapan kegiatan dari sosialisasi, pembekalan materi, analisis konsesp, pemebekalan tigan model pembelajaran sains (model berbasis laboratorium, model interaktif berbasis komputer, dan model brbasis proyek sains), workshop pengembangan ketiga model 
pembelajaran, dan implementasi model pembelajaran di kelas berjalan dengan baik. Peserta antusias mengikuti seluruh kegiatan. Kehadiran peserta (guru IPA) mengikuti latihan setiap kegiatan cukup tinggi (>80\%) dan inisiatif bertanya didominasi oleh peserta pelatihan.

Sosialisasi program cukup menentukan kelancaran kegiatan. Jadwal semester pembelajaran sains aspek kimia yang jatuh pada bulan Nopember sedikit menjadi kendala di awal untuk mengimplementasikan program di kelas. Tim pelaksana mengusulkan implementasi (di kelas) rancangan program pembelajaran (yang akan dihasilkan dari kegiatan workshop pada bulan Juli-Agustus) dapat dilaksanakan pada bulan September-Oktober, karena pelaporan keseluruhan kegiatan IbM ini dilakukan pada bulan Nopember. Ketika pertemuan pertama dengan seluruh peserta dalam kegiatan sosialisasi program, guru-guru belum berani mengubah jadwal urutan pembelajaran kompetensi dasar sains, meskipun masih dalam satu semester. Mereka masih membicarakannya dalam pertemuan MGMP Kecamatan yang biasanya dilakukan setiap bulan.

Alasan yang diajukan oleh tim pelaksana dianggap cukup rasional. MGMP kemudian menyetujui pertukaran jadwal yang diusulankan. Pemindahan urutan jadwal pembelajaran kompetensi sains lain dalam satu semester dan bahkan antar semester dalam sebuah jenjang pendidikan (seperti jenjang SMP) masih dimungkinkan dalam KTSP jika diperlukan untuk mengoptimalkan hirarki pembelejaran konsep dalam rangka meningkatkan kualitas pembelajaran. Pertukaran urutan jadwal pembelajaran "pemisahan campuran (aspek kimia)" dan pembelajaran "wujud zat dan perubahannya (aspek fisika)" pada semester kelas VII semester 1 tidak secara signifikan menyulitkan penguasaan kompetensi secara keseluruhan pembelajaran sains di kelas VII semester 1. Bahkan pembelajaran "unsur dan senyawa" di kelas VII perlu disatukan dengan pembelajaran partikel materi dan reaksi kimia di kelas VIII, karena definisi unsur dan senyawa tidak mungkin dipahami di kelas VII tanpa dukungan pengetahuan partikel materi dan reaksi kimia yang diprogramkan di kelas VIII.

Kegiatan pembekalan materi pelajaran sains aspek kimia SMP berjalan dengan baik, meskipun peserta agak lambat menguasai materi pembekalan dan menyelesaikan tugas latihan. Selama kegiatan pembekalan materi bahan kajian sains aspek kimia tersebut, guru menunjukkan apresiasi yang tinggi, meskipun banyak pertanyaan dari para peserta yang mengindikasikan bahwa kebanyakan guru IPA SMP kurang memahami konsep-konsep sains aspek kimia bagi siswa SMP seperti konsepsi asam- 
basa kelas VII menuntut sampai adanya ion $\mathrm{H}^{+}$, rumus kimia, dan asam lemah/kuat (terlalu tinggi mestinya hanya demonstarsi pengenalan asam/basa dengan kertas lakmus atau $\mathrm{pH}$ meter, siswa belum diajar partikel materi dan rumus kimia); beda zat (zat murni) dengan materi; beda atom dengan unsur; dan beda molekul dan senyawa. Pertanyaan-pertanyaan mengenai konsespsi tentang konsep-konsep dasar sains dan pernyataan konsepsi yang termasuk miskonsepsi masih banyak muncul ketika kegiatan kedua (analisis konsep) sudah dimulai.

Sebelum kegiatan ini dilaksanakan guru-guru IPA SMP relatif sulit memehami konsep-konsep dasar kimia bagi pebelajar pemula yang menuntut keterkaitan kajian makroskopik, mikoskopis, dan simbolik mulai dari contoh-contoh konkrit dengan partikel atau simbol (rumus kimia) yang sederhana untuk membangkitkan minat belajar. Pemberian teks materi pembekalan dimaksudkan untuk menyamakan persepsi atau konsepsi tentang konsep-konsep sains aspek kimia dan organisasi pembelajarannya di SMP sesuai dengan tahapan perkembangan pebelajar kimia pemula. Buku-buku sains yang beredar di pasar banyak menggunakan contoh-contoh zat atau bahan kimia yang tidak sesuai dengan perkembangan belajar kimia siswa SMP sebagai pebelajar kimia pemula dan juga banyak ditemukan miskonsepsi. Peserta sangat menyambut kehadiran kelima unit teks bahan kajian sains aspek kimia untuk siswa SMP tersebut. Penyedian bimbingan jika diperlukan terutama melalui telpon/internet kapan saja maupun secara langsung di lapang. Setelah mengikuti pembekalan materi dan analisis konsepsi pemahaman materi menjadi lebih baik yang terindikasi dari rumusan aspek-aspek dalam analisis konsep yang membaik.

Kegiatan analisis konsepsi (kegiatan kedua dalam pelatihan) dengan menggunakan format analisis konsepsi dari Herron (Tabel 2) cukup efektif untuk melakukan perbaikan konsepsi tentang konsep-konsep dasar kimia untuk jenjang SMP. Peserta sangat antusias mengikuti pembekalan analisis konsep dan sangat aktif bertanya dan berpendapat. Bahkan ketika latihan analisis konsep sudah di mulai, guruguru cendrung masih kurang percaya diri untuk menentukan konsep dan merumuskan konsepsinya. Sepanjang kegiatan anlisis konsep juga secara tidak langsung masih diwarnai dengan pembekalan materi. Pada akhir hari pertama kegiatan pembekalan dan latihan analisis konsep, guru disarankan untuk melanjutkan analisis konsep di rumah dan di bahas pada pertemuan berikutnya. Pada pertemuan kedua analisis konsep belum berhasil mengidentifikasi semua konsep dari bahan kajian materi dan sifatnya untuk SMP. Oleh karena keterbatasan alokasi waktu pelaksanaan analisis 
konsep, hasil identifikasi dan analisis terhadap konsep-konsep yang belum teridentifikasi diberikan oleh tim pelaksana kegiatan pelatihan untuk dipertimbangkan.

Hasil analisis konsep dari beberapa contoh konsep yang sudah berhasil diidentifikasi disajikan dalam Tabel 2.

Tabel 2. Hasil Analisis Kosepsi dari Beberapa Contoh Konsep Sains Aspek Kimia SMP

\begin{tabular}{|c|c|c|c|c|c|c|c|c|c|}
\hline \multirow{2}{*}{$\begin{array}{c}\text { Label } \\
\text { Kon- } \\
\text { sep }\end{array}$} & \multirow[b]{2}{*}{$\begin{array}{l}\text { Definisi } \\
\text { Konsep }\end{array}$} & \multirow{2}{*}{$\begin{array}{c}\text { Jenis } \\
\text { kon- } \\
\text { sep }\end{array}$} & \multicolumn{2}{|l|}{ Atribut } & \multicolumn{3}{|c|}{\begin{tabular}{|l|} 
Posisi Konsep \\
\end{tabular}} & \multirow[b]{2}{*}{ Contoh } & \multirow[b]{2}{*}{$\begin{array}{l}\text { Non- } \\
\text { contoh }\end{array}$} \\
\hline & & & Kritis & $\begin{array}{c}\text { Varia } \\
\text {-bel }\end{array}$ & \begin{tabular}{|l|}
$\begin{array}{l}\text { Supra- } \\
\text { ordinat }\end{array}$ \\
\end{tabular} & $\begin{array}{l}\text { Koor- } \\
\text { dinat }\end{array}$ & $\begin{array}{l}\text { Subor- } \\
\text { dinat }\end{array}$ & & \\
\hline \multicolumn{10}{|c|}{ Kelas VII } \\
\hline Materi & $\begin{array}{l}\text { Materi } \\
\text { menempati } \\
\text { ruang, dan } \\
\text { mempunyai } \\
\text { massa }\end{array}$ & $\mathrm{K}$ & $\begin{array}{l}\cdot \text { menempati } \\
\text { ruang (mem- } \\
\text { punyai volum) } \\
\text { - mempunyai } \\
\text { massa }\end{array}$ & \begin{tabular}{|c|} 
besar \\
ruang \\
besar \\
massa
\end{tabular} & - alam & $\begin{array}{l}\text { - ener } \\
\text { gi }\end{array}$ & $\begin{array}{l}\text { - zat } \\
\text { - Cam- } \\
\text { puran }\end{array}$ & \begin{tabular}{|l} 
- batu \\
- air \\
- udara
\end{tabular} & $\begin{array}{l}\text { - panas } \\
\text { - listrik }\end{array}$ \\
\hline Zat & \begin{tabular}{|l|} 
Zat berupa \\
materi tunggal \\
(murni), \\
mempunyai \\
partikel-parti- \\
kel yang sama, \\
dan tidak dapat \\
dipisah-kan \\
secara fisika \\
mengha-silkan \\
zat lain
\end{tabular} & $\begin{array}{l}\text { AbK } \\
\\
\end{array}$ & $\begin{array}{l}\text { - materi } \\
\text { tunggal/ } \\
\text { murni } \\
\text { - mempu-nyai } \\
\text { parti-kel } \\
\text { materi yang } \\
\text { sama } \\
\text { - tidak dapat } \\
\text { dipisahkan } \\
\text { secara fisika }\end{array}$ & \begin{tabular}{|l}
- wuju \\
$\mathrm{d}$ \\
- \\
jenis \\
parti \\
kel
\end{tabular} & materi & $\begin{array}{l}\text { - cam- } \\
\text { pura } \\
\text { n }\end{array}$ & $\begin{array}{l}\text { - unsur } \\
\text { - senya } \\
\text { wa }\end{array}$ & \begin{tabular}{|l|} 
\\
- air \\
- Oksi- \\
gen
\end{tabular} & $\begin{array}{l}\text { - udara } \\
\text { - air } \\
\text { laut } \\
\text { - tanah }\end{array}$ \\
\hline $\begin{array}{l}\text { Campu } \\
\text { ran }\end{array}$ & \begin{tabular}{|l} 
Campuran \\
terdiri dari dua \\
zat atau lebih \\
yang dapat \\
dipisahkan \\
secara fisika \\
dan masih \\
mempunyai \\
sifat zat-zat \\
penyusun-nya
\end{tabular} & BP & $\begin{array}{l}\text { - terdiri dari dua } \\
\text { zat atau lebih } \\
\text { - zat-zat } \\
\text { penyusun } \\
\text { dapat } \\
\text { dipisahkan } \\
\text { secara fisika } \\
\text { - masih } \\
\text { mempunyai } \\
\text { sifat zat-zat } \\
\text { penyusun-nya }\end{array}$ & \begin{tabular}{|c|}
- maca \\
m zat \\
penyu \\
sun \\
- kadar \\
/kom \\
posisi
\end{tabular} & materi & - zat & $\begin{array}{l}\text { - larutan } \\
\text { - cam- } \\
\text { puran } \\
\text { hete- } \\
\text { rogen }\end{array}$ & \begin{tabular}{|l} 
- tanah \\
- air \\
yang \\
berlu \\
mpur \\
- batuan
\end{tabular} & $\begin{array}{l}\text { - air } \\
\text { - emas } \\
\text { oksig } \\
\text { en }\end{array}$ \\
\hline
\end{tabular}

Pembekalan tiga jenis model pembelajaran inovatif sains aspek kimia (model pembelajaran berbais kegiatan laboratorium, model pembelajaran interaktif berbasis komputer, model pembelajaran berbais proyek sains) dilakukan sekali (satu hari) dan dilanjutkan dengan workshop membuat prangkat pembelajaran ketiga model pembelajaran sebanyak tiga kali (setiap sabtu selama tiga minggu). Rangkuman komparasi karakteristik ketiga jenis model pembelajaran untuk topik tertentu telah 
disajikan dalam Tabel 1 di atas. Ketiga jenis model pembelajaran tersebut dianggap merepresentasikan penyesuaian model pembelajaran dengan karakteristik isi kompetensi sains aspek kimia dan perkembangan belajar kimia bagi siswa SMP (pemula membangun konsepsi kimia) yang melibatkan kajian aspek makroskopik, mikroskopik, dan/atau simbolik.

Model pembelajaran zat dan campuran berbasis laboratorium dan model pembelajaran interaktif berbasis komputer dapat diimplementasikan langsung di kelas. Guru memilih untuk menerapkan model pembelajaran berbasis kegiatan proyek sains pada kegiatan ekstrakurikuler karya ilmiah dan tidak melakukan pada kelas biasa karena memerlukan waktu yang cukup lama. Kedua model (model pembelajaran berbasis kegiatan laboratorium dan model pembelajaran interaktif berbasis komputer) diimplementasikan di setiap sekolah oleh guru-guru IPA SMP di sekolah terebut secara team teaching yang didampingi oleh tim dosen (pelatih). Efektifitas pelaksanaan kegiatan terutama dilihat dari kecocokan tanggapan guru dan siswa terhadap implementasi model pemebalajaran (hasil kegiatan latihan) di kelas.

Guru antusias menerapkan rancangan pembelajaran di kelas. Beberapa guru bahkan datang ke SMP lain sebagai observer pada tampilan pembelajaran yang dilakukan oleh peserta dari sekolah tersebut. Kegiatan implementasi program pembelajaran di kelas hanya wajib dihadiri anggota tim mengajar di sekolah tersebut, namun peserta dari sekolah lain boleh sebagai observer atau membantu tim mengajar yang diobservasi, di samping tim pelatih (dosen) sebagai pendamping.

Hanya model pembelajaran zat dan campuran berbasis laboratorium dan model pembelajaran interaktif berbasis komputer dapat diimplementasikan di kelas. Model pembelajaran berbasis kegiatan proyek tidak dilakukan pada kelas biasa karena memerlukan waktu yang cukup lama dan akan dilakukan pada siswa yang memilih ekstrakurikuler karya ilmiah (belum dilaksanakan). Kedua model (model pembelajaran berbasis kegiatan laboratorium dan model pembelajaran interaktif berbasis komputer) diimplementasikan di setiap sekolah oleh guru-guru IPA SMP di sekolah terebut secara team teaching yang didampingi oleh tim dosen (pelatih).

Pada awalnya guru merasa kurang nyaman didampingi oleh dosen pelatih. Namun karena dosen menempatkan posisi sebagai observer dan sekaligus sebagai kolega yang membantu mengefektifkan pelakanaan pembelajaran oleh guru, dosen pada pertemuan berikutnya cukup diterima sebagai kolega. Refleksi pelaksanaan implementasi model pembelajaran di sekolah setempat berdasarkan hasil observasi 
dosen pendamping dan guru dalam team teaching. Tanggapan berupa STS (sangat tidak setuju), TS (tidak setuju), BS (biasa saja), S (setuju), dan SS (sangat setuju) dari sejulam sampel siswa SMP di Kecamatan Tejakula terhadap pembelajaran yang mengikuti pembelajaran dengan model dan perangkat pembelajaran untuk model pemebalajaran zat dan campuran berbasis kegiatan laboratorium disajikan pada Tabel 3 dan untuk model pembelajaran interaktif unsur, senyawa, dan campuran berbasis komputer disajikan dalam Tabel 4. Sementara tanggapan yang berupa TS (tidak setuju), BS (biasa saja), dan S (setuju) dari guru peserta pelatihan terhadap pelaksanaan kegiatan pelatihan ini disajikan dalam Tabel 5

Tabel 3. Tanggapan Siswa SMP Kelas VII Kecamatan Tejakula yang Mengikuti Pembelajaran Zat dan Campuran Berbasis Kegiatan Laboratorium

\begin{tabular}{|c|c|c|c|c|c|c|}
\hline \multirow{2}{*}{ No } & \multirow{2}{*}{ Pernyataan } & \multicolumn{5}{|c|}{ Tanggapan (\% Siswa) } \\
\hline & & STS & TS & BS & $\mathbf{S}$ & SS \\
\hline 1 & Pengetahuan zat dan campuran disajikan dengan jelas. & 0 & 0 & 2 & 39 & 18 \\
\hline 2 & Pelatihan melakukan pengamatan dilakukan dengan baik. & 0 & 0 & 1 & 21 & 37 \\
\hline 3 & $\begin{array}{l}\text { Pelatihan kemampuan melakukan percobaan untuk membuat } \\
\text { kesimpulan dilakukan dengan baik. }\end{array}$ & 0 & 0 & 2 & 43 & 14 \\
\hline 4 & $\begin{array}{l}\text { Pelatihan kemampuan untuk melakukan perhitungan dasar } \\
\text { dilakukan dengan jelas seperti menghitung perbandingan massa zat } \\
\text { dalam campuran }\end{array}$ & 0 & 1 & 8 & 46 & 4 \\
\hline 5 & $\begin{array}{l}\text { Pengetahuan dan proses untuk menguatkan kemampuan kimia } \\
\text { seperti menggunakan mssa jenis zat dalam larutan diberikan } \\
\text { dengan baik. }\end{array}$ & 0 & 0 & 6 & 41 & 12 \\
\hline 6 & $\begin{array}{l}\text { Langkah-langkah belajar memeberi kesempatan kepada siswa } \\
\text { untuk menemukan sendiri pengetahuan yang dipelajari (tidak } \\
\text { dipaksa untuk menerima pengetahuan yang diceramahkan guru). }\end{array}$ & 0 & 6 & 13 & 31 & 9 \\
\hline 7 & $\begin{array}{l}\text { Langkah-langkah kerja praktikum atau diskusi dalam lembar } \\
\text { kegiatan siswa (LKS) disajikan dengan jelas. }\end{array}$ & 0 & 0 & 3 & 42 & 14 \\
\hline 8 & Tugas-tugas dalam LKS adalah jelas. & 0 & 0 & 12 & 40 & 8 \\
\hline 9 & Bahan pelajaran dituliskan dengan jelas. & 0 & 0 & 1 & 26 & 7 \\
\hline 10 & $\begin{array}{l}\text { Komentar atau masukan dari guru terhadap hasil kerja tugas-tugas } \\
\text { untuk perbaikan jawaban atau hasil dapat mengarahkan siswa } \\
\text { memperbaiki dan memahami jawaban yang benar. }\end{array}$ & 0 & 0 & 1 & 38 & 19 \\
\hline 11 & Pelajaran kimia hendaknya terus diberikan & 0 & 4 & 10 & 34 & 10 \\
\hline 12 & Pengetahuan kimia sangat berguna pada kehigupan sehari-hari & 0 & 0 & 7 & 33 & 19 \\
\hline
\end{tabular}

Keterangan: STS = sangat tidak setuju; TS = tidak setuju; BS = biasa-biasa saja; $\mathrm{S}=$ setuju), dan $\mathrm{SS}=$ sangat setuju.

Tabel 4. Tanggapan Siswa SMP Kelas VIII Kecamatan Tejakula yang Mengikuti Pembelajaran Unsur, Senya, dan Campuran Berbasis Kegiatan Interaktif Berbantuan Komputer

\begin{tabular}{|c|c|c|c|c|c|c|}
\hline \multirow{2}{*}{ No } & \multirow{2}{*}{ Pernyataan } & \multicolumn{5}{|c|}{ Tanggapan (\% Siswa) } \\
\hline & & STS & TS & BS & $\mathbf{S}$ & SS \\
\hline 1 & Pengetahuan unsur, senyawa, dan campuran disajikan dengan jelas. & 0 & 0 & 6 & 22 & 24 \\
\hline
\end{tabular}




\begin{tabular}{|c|c|c|c|c|c|c|}
\hline 2 & $\begin{array}{l}\text { Siswa dilatih dengan baik menggunakan hasil pengamatan dari } \\
\text { pengalaman sendiri dan informasi dari sumber lain (tayangan } \\
\text { komputer) dalam belajar unsur, senyawa, dan campuran. }\end{array}$ & 0 & 4 & 4 & 28 & 16 \\
\hline 3 & $\begin{array}{l}\text { Siswa dilatih dengan baik menggunakan model partikel materi } \\
\text { melalui program interaktif komputer untuk memahami unsur, } \\
\text { senyawa, dan campuran. }\end{array}$ & 0 & 0 & 5 & 22 & 25 \\
\hline 4 & $\begin{array}{l}\text { Siswa tidak akan memahami unsur, senyawa, dan campuran } \\
\text { dengan baik tanpa penggunaan model partikel materi dari unsur, } \\
\text { senyawa, dan campuran. }\end{array}$ & 0 & 10 & 21 & 15 & 6 \\
\hline 5 & $\begin{array}{l}\text { Langkah-langkah kegiatan dalam LKS (termasuk program } \\
\text { interaktif komputer) dengan jelas mengarahkan siswa menemukan } \\
\text { sendiri pengertian unsur, senyawa, dan campuran (tidak dipaksa } \\
\text { menghafal pengetahuan yang diceramahkan guru). }\end{array}$ & 2 & 10 & 10 & 23 & 7 \\
\hline 6 & Tugas-tugas dalam LKS adalah jelas. & 1 & 6 & 21 & 17 & 7 \\
\hline 7 & Bahan pelajaran ditulis dengan jelas. & 0 & 3 & 11 & 30 & 8 \\
\hline 8 & $\begin{array}{l}\text { Komentar atau catatan koreksi dari guru terhadap jawaban atau } \\
\text { hasil kerja tugas-tugas mengarahkan siswa memperbaiki jawaban } \\
\text { yang salah dan memahami jawaban yang benar. }\end{array}$ & 0 & 0 & 4 & 18 & 31 \\
\hline
\end{tabular}

Tabel 5. Distribusi Tanggapan Guru-guru IPA SMP Kecamatan Tejakula Sebelum dan Setelah Mengikuti Pelatihan terhadap Aspek-aspek Pembelajaran Sains Aspek Kimia SMP

\begin{tabular}{|c|c|c|c|c|c|c|c|}
\hline \multirow{2}{*}{ No } & \multirow{2}{*}{ Pernyataan } & \multicolumn{3}{|c|}{\begin{tabular}{|l|} 
Sebelum \\
Pelatihan
\end{tabular}} & \multicolumn{3}{|c|}{$\begin{array}{l}\text { SetelahPel } \\
\text { atihan }\end{array}$} \\
\hline & & $\begin{array}{l}\mathbf{T} \\
\mathbf{S}\end{array}$ & $\begin{array}{l}\text { B } \\
\text { S }\end{array}$ & $\mathbf{S}$ & & BS & $\mathbf{S}$ \\
\hline 1 & $\begin{array}{l}\text { Mampu mengindentifikasi konsep-konsep dasar aspek kimia } \\
\text { untuk siswa SMP }\end{array}$ & 5 & 4 & 5 & 0 & 0 & 13 \\
\hline 2. & $\begin{array}{l}\text { Mampu membuat konsepsi ilmiah sebagian besar konsep-konsep } \\
\text { dasar aspek kimia dengan menghu-bungkan sifat konkrit (aspek } \\
\text { makroskopik), partikel materi (aspek mikroskopik), dan rumus } \\
\text { kimia (aspek simbolik) dari materi untuk siswa SMP }\end{array}$ & 7 & 5 & 2 & 0 & 0 & 13 \\
\hline 3 & $\begin{array}{l}\text { Mampu menunjukkan sifat-sifat konkrit/makroskopik (sifat yang } \\
\text { dapat diamati) seperti sifat mudah terbakar, mengendap, } \\
\text { perubahan warna dari materi) }\end{array}$ & 7 & 4 & 3 & 0 & 0 & 13 \\
\hline 4 & $\begin{array}{l}\text { Mampu menjelaskan partikel materi atau aspek mikroskopik } \\
\text { (atom, molekul, atau ion) sebagai penentu sifat dan identitas } \\
\text { materi }\end{array}$ & 5 & 5 & 4 & 0 & 0 & 13 \\
\hline 5 & $\begin{array}{l}\text { Sulit menjelaskan rumus kimia atau simbol-simbol kimia dari } \\
\text { suatu zat (pernyataan negatif) }\end{array}$ & 1 & 2 & 11 & 5 & 2 & 6 \\
\hline 6 & $\begin{array}{l}\text { Sulit menjelaskan terjadinya zat baru dengan model partikel } \\
\text { materinya (pernyataan negatif) }\end{array}$ & 0 & 1 & 12 & 6 & 0 & 7 \\
\hline 7 & $\begin{array}{l}\text { Sulit mengorganisasikan isi/konsep-konsep dalam pembelajaran } \\
\text { aspek kimia }\end{array}$ & 1 & 1 & 12 & 6 & 1 & 6 \\
\hline 8 & $\begin{array}{l}\text { Cenderung hanya menggunakan pendekatan deduktif (memberi } \\
\text { konsepsi/definisi di awal kemudian dilanjutkan dengan memberi } \\
\text { contoh-contoh atau pembuktian tentang konsepsi tersebut } \\
\text { (pernyataan negatif) }\end{array}$ & 4 & 1 & 9 & 7 & 3 & 3 \\
\hline 9 & $\begin{array}{l}\text { Mampu menggunakan pendekatan induktif (berangkat dari } \\
\text { contoh-contoh menuju simpulan) secara konsisten }\end{array}$ & 3 & 5 & 7 & 1 & 0 & 12 \\
\hline 10 & $\begin{array}{l}\text { Mampu menggunakan pendekatan deduktif (berangkat dari } \\
\text { simpulan/definisi konsep diikuti contoh-contoh pembuktian) }\end{array}$ & 1 & 5 & 8 & 2 & 1 & 10 \\
\hline
\end{tabular}




\begin{tabular}{|c|l|c|c|c|c|c|c|}
\hline 11 & $\begin{array}{l}\text { Mampu menetukan/memilih dan menerapkan metode-metode } \\
\text { pembelajaran dengan efektif }\end{array}$ & 3 & 4 & 7 & 0 & 1 & 12 \\
\hline 12 & $\begin{array}{l}\text { Mampu menetukan/memilih dan menerapkan teknik-teknik } \\
\text { pembelajaran dengan efektif (seperti teknik diskusi kelompok } \\
\text { kecil/panel) dalam penggunaan metode diskusi }\end{array}$ & 2 & 4 & 8 & 0 & 2 & 11 \\
\hline 13 & $\begin{array}{l}\text { Mampu menetukan/memilih dan menerapkan model } \\
\text { pembelajaran yang berbasis kegiatan laboratorium }\end{array}$ & 5 & 4 & 5 & 0 & 1 & 12 \\
\hline 14 & $\begin{array}{l}\text { Mampu menetukan/memilih dan menerapkan model } \\
\text { pembelajaran kimia yang berbasis program interaktif computer } \\
\text { sesuai tingkat perkembangan siswa SMP }\end{array}$ & 5 & 3 & 6 & 0 & 0 & 13 \\
\hline 15 & $\begin{array}{l}\text { Mampu menetukan/memilih dan menerapkan model } \\
\text { pembelajaran kimia yang berbasis kegiatan projek sains sesuai } \\
\text { tingkat perkembangan siswa SMP }\end{array}$ & 6 & 2 & 6 & 1 & 1 & 11 \\
\hline
\end{tabular}

Keterangan: $\mathrm{TS}=$ tidak setuju; $\mathrm{BS}=$ biasa-biasa saja; $\mathrm{S}=$ setuju

Secara keseluruhan baik guru-guru maupun siswa memberi tanggapan postif terhadap kegiatan pelatihan ini.

Kegiatan pengembangan rencana pelaksanaan pembelajaran (RPP) dengan ketiga model pembelajaran yang dilatihkan cendrung dapat dilanjutkan sendiri oleh guru-guru IPA. Model pembelajaran yang sama dapat digunakan untuk mengajarkan materi sains aspek kimia lain dengan karakteristik yang sama. Beberapa guru IPA telah menyampaikan niatnya untuk melakukan penelitian tindakan kelas (PTK) dengan menggunakan model pembelajaran yang dihasilkan untuk meningkatkan hasil belajar siswa.

\section{SIMPULAN}

Antusiasme dan tingkat partisifasi guru-guru IPA mengikuti kegiatan P2M ini tinggi. Kegiatan P2M ini telah menghasilkan beberapa produk yang sangat bermanfaat bagi pelaksanaan pembelajaran sains aspek kimia secara bermakna di SMP. Pertama, program pelatihan yang melibatkan tahapan sosialisasi prigram, pembekalan materi, pelatihan analisis konsepsi, workshop pengembangan model pembelajaran, pendampingan latihan penerapan model di kelas, dan refleksi hasil implementasi model pembe;lajaran dan penyempurnaannya. Kedua, hasil identifikasi dan analisis konsep sains aspek kimia untuk siswa SMP dengan sejumlah aspek penting (konsepsi atau definesi konsep, cirri-ciri konsep, jenis konsep, posisi konsep, contoh dan noncontoh dari setiap konsep) akan memberi arahan pada pemilihan strategi pembelajaran konsep tersebut secara efektif dan menghindari terjadinya miskonsepsi pada pebelajar yang diajar dengan perangkat pembelajaran untuk model tersebut. Ketiga, tiga model pembelajaran sains aspek kimia yakni model pembelajaran berbasi kegiatan laboratorium, model pembelajaran berbasis interaktif computer, dan model 
pembelajaran sains berbasis kegiatan proyek sains cukup merepresentasikan dan mengakomodasi model-model pembelajaran sains secara bermakna. Kemampuan mengembangkan ketiga model ini merupakan asset berharga dalam pembelajaran sains secara efektif sesuai dengan karakteristik materi pelajaran. Baik guru maupan siswa memberi tanggapan positif terhadap program pelatihan ini.

Rencana pelaksanaan pembelajatan (RPP) dan perangkat pembelajaran dari model yang dikembangkan sangat penting untuk menjamin implementasi aspek-aspek belajar dalam model pembelajaran yang dirancang. Kejelasan rancangan isi, kefektifan organisasi, dan ketepatan asesmen pembelajaran dalam RPP akan menentukan efektifitas pencapaian tujuan dan sasaran belajar. Dukumen RPP dan perangkat pembelajarannya yang berkualitas dapat digunakan langsung oleh guru lain untuk mengajarkan konsep-konsep tersebut atau dirujuk dalam pembuatan RPP untuk konsep-konsep sejenis.

Beberapa kendala dialami oleh guru dan siswa SMP. Isi dan sajian isi sains aspek kimia dalam buku-buku pelajaran sains untuk siswa SMP yang digunakan disekolah dan tersedia dipasar masih banyak mengandung miskonsepsi, belum menumbuhkan motivasi belajar aspek kimia, dan kurang cocok bagi siswa SMP. Guruguru IPA SMP belum terbiasa merumuskan sendiri unit-unit teks pelajaran sesuai dengan kebutuhan sendiri. Guru cendrung menggunakan langsung buku-buku pelajaran yang tersedia di pasar tanpa memperhatikan kualitas isinya. Di samping itu ketersediaan guru-guru IPA SMP yang berlatar khusus pembelajaran sains di SMP sangat tidak memadai. Jurusan khusus Pendidikan Sains/IPA dengan lulusan yang sekaligus menguasai pembelajaran sains aspek Fisika, Biologi, Kimia, dan IPBA) untuk SMP masih sangat jarang di Indonesia, sementara formasi guru-guru muda (guru baru) IPA didominasi oleh lulusan Pendidikan Fisika dan Pendidikan Biologi.

\section{Ucapan terima kasih}

Penghargaan yang tinggi diberikan kepada peserta pelatihan yang telah berkomitmen memperbaiki pembelajaran aspek kimia terutama bagi pebelajar kimia pemula karena telah memberikan lampu penerang dalam kegelapan pengetahuan dasar kehidupan kepada generasi ke depan. Ucapan terima kasih disampaikan kepada Ditlitabmas Dikti atas dana program IbM tahun 2011, LPM Undiksha atas pengkoordinasian dan pengadministrasian program, dan semua pihak yang telah membantu realisasi kegiatan pengabdian kepada masyarakat ini. 


\section{DAFTAR PUSTAKA}

American Association for the Advancement of Scinece. (1993). Benchmarks for Science Literacy: Project 2061. NewYork : Oxford University Press.

Arikunto, S. (1986). Dasar-Dasar Evaluasi Pendidikan. Jakarta : PT Bina Aksara

Costa, A.L.. (1985). (Ed.). Developing Minds A Resource Books for Teaching Thinking. United Stated of America : Association for Supervision and Curriculum Development.

Dahar, R.W. (1996). Teori-Teori Belajar. Cetakan Kedua. Jakarta : Penerbit Erlangga. Departemen Pendidikan Nasional. (2003). Kurikulum 2004 - Kerangka Dasar. Jakarta : Departemen Pendidikan Nasional

, (2006), Kurikulum Tingkat satuan Pendidikan. Jakarta : Departemen Pendidikan Nasional

Gabel, D. (1999). "Improving Teaching and Learning through Chemistry Education Research: A Look to the Feature". Journal of Chemical Education. 76, 548553.

McDuell, B. (1986). Chemistry 1 - 3 Foundation Skills for 11-14 Year olds (Study Aids). London : Charles Letts \& Co Ltd.

Nakhleh, M.B. (1992). "Why Some Students Don't Learn Chemistry”. Journal of Chemical Education. 69, 3, 191-195.

Rutherford F. J. and Ahlgren A.. (1990). Science for All Americans. New York :

\section{Oxford University Press.}

Sidi, I. (2002). Konsep Pendidikan Berorientasi Kecakapan Hidup melalui Pendidikan Berbasis Luas (BBE), Jakarta : Direktur Jendral Pendidikan Dasar dan Menengah Departemen Pendidikan Nasional.

Siskandar, H. (2003). Pelayanan Profesional Kurikulum 2004 - Penilaian Kelas. Jakarta : Depdiknas.

Stiggins, R, J. (1994). Student-Centered Clasroom assessment. New York : Maxwell Macmillan International.

Sudria, I.B.N. (2006). Peningkatan Kualitas Konsepsi Kimia Mahasiswa tentang Konsep-Konsep Dasar Kimia Melalui Optimalisasi Pengaitan Kajian Aspek Makroskopis, Mikroskopik, dan Simbolik pada Perkuliahan Kimia Dasar. Laporan hasil Penelitian pada STKIP Singaraja.

Sudria, I.B.N. (2007). Pengembangan Materi Ajar Kimia dan Pemecahan Materi Sulit. Makalah disajikan dalam workshop yang diselenggarakan oleh Keluarga Besar MGMP Kimia SMA Kabupaten Buleleng pada Tanggal 5 Oktober 2007

Sudria, I.B.N. (2008). Pengembangan Rubrik Asesmen Performan Keterampilan Dasar Kimia dalam Perkuliahan Kimia Dasar. Laporan Hasil Penelitia pada Universitas Pendidikan Ganesha Ainagaraja: tidak diterbitkan

Sudria, I.B.N. et al. (2000). Analisis Pembelajaran Konsep-konsep Kimia SLTP di Kota Singaraja. Laporan hasil Penelitian pada STKIP Singaraja : tidak diterbitkan.

The Natonal Academy of Science. (1996). National Science Education Standars. Washington DC.: Nationat Academy Press.

Tim BBE Depdiknas. (2001). Konsep Pendidikan Kecakapan Hidup (Life Skill Education) (Buku I). Depdiknas. 
Zainul, A. (2001). Alternative Assessment Applied Approach Mengajar di Perguruan Tinggi Buku 2.09. Jakarta : Pusat Antar Universitas untuk Peningkatan dan Pengembangan Aktivitas InstruksionalDirjen Dikti Depdiknas. 